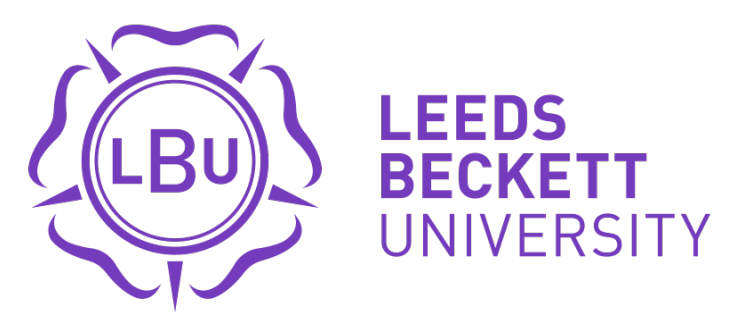

Citation:

Flintoff, A (2015) Playing the 'Race' card? Black and minority ethnic students' experiences of physical education teacher education. Sport, Education and Society, 20 (2). 190 - 211. ISSN 1357-3322 DOI: https://doi.org/10.1080/13573322.2012.745397

Link to Leeds Beckett Repository record:

https://eprints.leedsbeckett.ac.uk/id/eprint/261/

Document Version:

Article (Accepted Version)

The aim of the Leeds Beckett Repository is to provide open access to our research, as required by funder policies and permitted by publishers and copyright law.

The Leeds Beckett repository holds a wide range of publications, each of which has been checked for copyright and the relevant embargo period has been applied by the Research Services team.

We operate on a standard take-down policy. If you are the author or publisher of an output and you would like it removed from the repository, please contact us and we will investigate on a case-by-case basis.

Each thesis in the repository has been cleared where necessary by the author for third party copyright. If you would like a thesis to be removed from the repository or believe there is an issue with copyright, please contact us on openaccess@leedsbeckett.ac.uk and we will investigate on a case-by-case basis. 


\section{Playing the 'Race' Card? Black and minority ethnic students' experiences of Physical Education teacher education.}

\section{Introduction}

This paper reports on a study that explored the experiences of black and ethnic minority (BME) students of their physical education teacher education (PETE) programmes in universities in England. Widening the ethnic diversity of those choosing to enter the teaching profession in England has been a key policy objective of the Training and Development Agency (TDA) - the government agency responsible for teacher education - not least since the introduction of recent legislation requiring all public bodies to ‘proactively promote racial equality’ (Commission for Racial Equality, 2002) . Whilst school cohorts are becoming increasingly ethically diverse, teacher education cohorts still lag some way behind. Acknowledging the limitations of ethnic monitoring (not least how 'ethnicity' is categorised to produce 'groups' and 'labels' such as 'BME', discussed further below) recent figures show that approximately $11 \%$ of new entrants into teacher education overall in England, are from BME backgrounds, compared to $16 \%$ of school children (TDA, 2008). However, the figures for PETE - programmes designed to produce specialist physical education (PE) teachers to work with secondary age (11-18 years) pupils - reveal significant levels of under-representation of BME candidates, compared to other subject specialisms. Across the five years leading up to 2007/8, the year in which the research reported here was carried out, average figures reveal a significant and enduring 'race' gap between those entrants into teaching as a whole (all 
phases/subjects) from a BME background at $11 \%$, and those specifically opting into PE at 2.94\% (Turner, 2007). Feminist research has shown PETE to be a gendered space (e.g. Brown and Rich, 2002; Dowling, 2008), but these statistics suggest that it is also a White space. Whilst research elsewhere on pupils' and university students' experiences and outcomes of education have centralised 'race' and ethnicity, and their intersections with gender and class (e.g. Mirza, 2009; Reay, et al, 2001), we need to know more about how these processes operate within PE, and specifically PETE. This article explores the complex issues surrounding 'race', ethnicity, gender and PETE through centralising the experiences of BME students.

Over the last decade or so, a number of studies have explored the impact of ethnic minority status on teachers’ professional socialisation, (e.g. Carrington et al, 2001; Basit et al, 2005; Basit et al, 2006), however none of these have adopted an explicitly intersectional approach, or focused on experiences within specific subject cultures. Evidence from the broader literature in sports studies points towards the centrality of the body as significant in processes of racialisation. For example, research exploring racism and the under-representation of BME participants in sport has highlighted the prevalence of stereotypical attitudes about their physicality and abilities held by coaches, administrators and spectators (e.g. Long, et al, 2009), and how these might differ between men and women (e.g. Scraton, et al, 2005). The specifically embodied nature of PE teaching may be an important factor in BME individuals' experiences of this aspect of teacher education. 
As yet, however, there has been little sustained attention paid to 'race' and ethnicity in PETE (but see Benn, 1996; 2002; Douglas and Halas, 2011; Fitzpatrick, 2011, Nelson, 2011). Earlier studies of PETE (including our own) have shown the impact of gender on students’ developing professional identities (e.g. Brown and Rich, 2002; Flintoff, 1993a; b), and the importance of teachers' gendered bodies as 'tools' in their work (Webb and Macdonald, 2007). However, these studies have adopted a 'single issue' approach, where the focus is on one aspect of identity (gender), with little acknowledgement of how other aspects of identity, such as 'race' and ethnicity are interwoven with gender. As a result, little is known about the way in which PETE is gendered and racialised $^{1}$.

Benn’s action research (Benn, 1996; 2002; Benn and Dagkas, 2006) is one important exception; it explores the inter-relationships between religion, ethnicity and culture in Muslim women's experiences of primary teacher education. Her research highlights both the heterogeneity Muslim women’s experiences, and their agency in negotiating a place within PE as a specific school subject. Whilst physical activity was valued as an important part of their faith, Benn also showed how many of the women were subject to racial and religious prejudice, particularly in the PE contexts, in school and at university; success on the course came through denying a significant part of their identity - through adopting identity 'stasis’ (Benn, 2002, p.68) - choosing not to talk about anything related to Islam, or being Muslim, or not speaking their mind, for fear of confrontation ${ }^{2}$.

PETE as a particular context where racial and ethnic difference is heightened is explored more recently by Douglas and Halas (2011) and Fitzpatrick (2011). In addition to 
marginalising the experiences of BME students as a focus of research, Douglas and Halas (2011) argue that we have also failed to address the hegemony of Whiteness within PETE as a particularly university space/subject area. Drawing on DuBois' 'psychological wages of Whiteness', they map the Whiteness of PETE within Canadian universities, including the lack of visible minority ${ }^{3}$ faculty, and highlight its social costs including the isolation and alienation felt by minority students, and the limiting effects of a curriculum that fails to equip new teachers with the necessary knowledge to work within contemporary, diverse societies. Fitzpatrick’s (2011) critical ethnography of PE in New Zealand, similarly, shows how racialised discourses of embodiment work to position Maori students differently from their Pakeha (European/non Maori) counterparts in school and university PE spaces, but also how students resist and challenge these.

The study reported here is set against this research and policy background. It aimed to explore BME students' experiences of PETE, and in doing so, address some of the limitations of our knowledge of PETE outlined above and identify the processes and practices that racialise PETE. The specific research questions were: What is the significance of ethnicity in BME students' developing teacher identities, and how are these negotiated and produced within PETE in relation to other social categories, such as gender? What can an understanding of BME students' experiences tell us about the ways in which PETE practice is racialised and gendered? (See Flintoff, 2008)

\section{Theoretical and methodological challenges in researching 'race' and ethnicity}


A major challenge in social theory remains how to theorise and research social identities and relations of 'race', gender, class, sexuality and ability (Anthias, 2001; Davies, 2009). Anthias (2008, p.7) notes that the concept of identity is a 'slippery one', as it is used to describe both our sense of 'who we are', but also our sense of 'social place and belonging' and these two are 'symbiotically connected'. Different researchers have sought to explore individuals’ experiences by placing more emphasis on one or other of these aspects. Those drawing on post structuralism seek to deconstruct bipolarized conceptions of identity as unitary, fixed, and static properties of individuals, arguing for them to be seen instead as heterogeneous, fluid, and multiple. Alternatively, those drawing on standpoint thinking or identity politics - whilst recognising the connection between categorization and the exercise of power - are wary of rejecting categories of difference all together, because of their use in political projects seeking to challenge structural and material inequalities resulting from racism, sexism and other forms of oppression. Bonnett and Carrington (2000), for example, have argued the systems of ethnic classification that have emerged in the UK have done so, in part, as a result of struggles by marginalised groups to have their distinctive identities and claims to full participation in civic and political life recognised. Politically and strategically, they argue, there remains a need for research centred on particular groups and their shared experiences. Indeed, in relation to the research reported here, the starting point was the TDA's ethnic monitoring of applications for PETE courses by ethnicity, using the 'official' government ethnic categories, as part of their 
responsibility to promote racial equality (see Commission for Racial Equality, 2002; 2008). However, researchers relying on racial and ethnic categories as the starting point for their research risks the dangers of what Gunaratnam (2003, p.28) has called a 'treacherous bind'; that is, where the research itself is in danger of ‘reproducing dominant conceptions of 'race’ and ethnicity'.... 'Race' and ethnicity get constructed as discrete, homogenous and fixed categories of difference, rather than as socially constructed, relational and socially located'.

In order to overcome these tensions and shortfalls, theoretically we position ourselves in a 'middle ground', between modernism and postmodernism,(Archer et al, 2001). We concur with Archer and her colleagues' suggestion that,

'within education, researchers share a general treatment of 'race', class, gender, sexuality and disability as socially constructed, fluid, shifting and non-discrete identities and hold a common awareness and commitment to addressing the associated, very 'real', inequalities (Archer, et al, 2001, p.42).

Anthias (1998; 2001; 2008) proposes an analytical framework that can both recognise and account for differences and inequalities that such a positioning entails. She argues that 'race' and ethnicity as social divisions are produced through the twin processes of differentiation (and identification) and positionality. In order to explore how these processes operate, Anthias (1998) argues that analysis needs to be at four levels: the experiential, intersubjective, organisational and the representation, each interlinked. It is 
not enough to explore the experiences of individuals without also seeing these as interlinked to social structures and relations. In researching BME students' experiences of PETE, the experiential level of analysis would be interested in the experiences of individuals, within specific locations, of being defined as 'different' (e.g. to what extent do BME students feel a sense of belonging or not belonging in PETE and how does this alter across different spaces or times?; the intersubjective, in the actions and practices that take place in relation to others; (e.g. how do White students or staff interact with BME students and vice versa?) the organisational level would focus on institutions' frameworks for the organisation of ethnic groups, and resource allocation (e.g. how is ethnic diversity visible (or not) in its everyday policies and practices); and the representational - the symbolic and representational means, the images and language/texts circulating in these spaces (e.g. what kind of discourses circulate about BME pupils/groups in PE?). By focusing on processes of differentiation and positionality, rather than static identity categories, she argues that this framework can account for difference at the level of individual experience and patterns of enduring inequalities. Such an analysis allows for a conception of agency on the part of individuals; identities and relations are not fixed and immutable, but shifting, fluid and specific in time and place.

As well as incorporating different levels of analysis, there is now a well established debate (at least within wider feminist studies, education and sports studies, if not yet within PE - see Flintoff et al, 2008), that has replaced an 'additive' approach to 
inequalities based on 'race', gender and other power relations, with one that recognises their intersections. As Brah (1996, p.109) has noted,

structures of class, racism, gender and sexuality are experienced simultaneously, and cannot be reduced to independent variables.... The oppression of each is inscribed within the other - is constituted by and is constitutive of each other.

Intersectionally, Mirza (2009) argues, is embodied - a lived experience. However, she argues that whilst a focus on lived experience is important, this is not enough. Lived experience has to be seen as 'an interpretation of the social world', and a demonstration of the ways in which regulatory discursive power and privilege are 'performed' or exercised in the everyday material world', and across particular spaces and times.

Adopting such a middle ground, intersectional theoretical approach, however, also raises important issues for how difference is operationalised in research practice. Our research was funded by the TDA, and focused on a particular group of students categorised as ‘BME’ (see Table 1 below for details); drawing on Gunaratnam (2008), we aimed to work 'with and against' these ethnic categories in our research practice as detailed below. In addition, our position as White researchers raises significant methodological questions about researching across difference and we discuss these elsewhere in full (Flintoff and Webb, 2012); however, we acknowledge that these remain ongoing and important issues that arguably White researchers (and particularly in PE) have barely begun to address. 


\section{The research}

The research built on an earlier quantitative analysis of BME PETE recruitment data (Turner, 2007). We used semi-structured interviews and questionnaires with 25 participants that self-identified with one of the ethnic groups in the TDA broader description of 'BME' (see Table 2). Given the low numbers of BME students in PETE nationally (see Table 1), in order to recruit sufficient participants, students from five universities, and the last two years of alumni, were invited to take part ${ }^{4}$. These were all major PETE providers, running either undergraduate Bachelor of Arts/Science Honours courses, with Qualified Teacher Status (QTS), and/or one year Postgraduate Certificate in Education courses, and had staff interested in and committed to the research ${ }^{5}$.

Insert Table 1 about here

Of the total of 63 BME students who were recorded in TDA statistics as attending the five case-study institutions over these three years (2005/6- 2007/8), 25 chose to participate in the study (a $40 \%$ response rate). 17 were current students, and 8 were recent graduates in their first or second year of teaching PE in school. Of the 25 participants that were interviewed, 14 were men, and 11 women (see Table 2 below).

We used a number of strategies in striving to work against, as well as with, ethnic categories including highlighting our concerns about their use in our initial invitation letter to participants, and discussing their adequacy with participants as part of the 
interview (see Flintoff and Webb, 2012). Whilst trying to work in this way, paradoxically, the small numbers of BME students in PETE raised significant issues for ensuring anonymity. To protect participants' identity, we use the broader categories of 'Black', 'Asian', and 'Mixed race' here (as used, for example, in the annual UK population Census), rather than the more specific ethnic categories such as Black Caribbean or Pakistani (see Table 2) or students' self definitions. For the same reasons, we have chosen not to use pseudonyms, since names are often indicative of particular cultures and/or religions. Our use of numbers to distinguish participants is rather impersonal and somewhat unusual in qualitative research, and we recognise that we may be accused of doing little to challenge the view of ethnicity as homogeneous, static categories through these compromises; however, preserving our participants' anonymity took precedence. We do discuss the complexities of experience in the research commentary, rather than linking these specifically to individual viewpoints.

Insert Table 2 about here

The main method of data collection was through semi-structured interviews, lasting between one and two and half hours. All interviews were taped with permission, and conducted face-to-face apart from four, conducted over the telephone to accommodate distant school placements. Interview transcripts were fully transcribed and each initially coded and analysed thematically by two members of the research team, the interviewer, and the lead researcher who read all transcripts (see Flintoff, 2008; Flintoff and Webb, 2012). Key themes were then collated and refined by the lead researcher (Flintoff) before 
being presented back to the research team at a later group discussion. Drawing on feminist and post positivist paradigms, we argue that there is no one 'truth' waiting to be uncovered, only knowledge that is partial and constructed (Guba and Lincoln, 2005). However, like Holland et al (1998), we have endeavoured to engage in rigorous, trustworthy analysis, through attending to the interactions between the participants' meanings, interpretations of these in light of our feminist/critical theory, and our explanations of any differences between the understandings of our participants and ourselves. This has entailed us in an ongoing process of reflexivity which has informed our analysis of the data.

In addition to the interviews, we also used a questionnaire (adapted from Carrington et al's 2001 study with permission) that could be returned anonymously. In reflecting on the power of our own positions, both as lecturers involved in delivering aspects of the students' PETE programmes, and as White researchers, we felt it was important to include a mechanism by which students could report their experiences anonymously. In fact, few students did use the questionnaire to report experiences of racism; however the questionnaire data was useful for supporting the more in-depth insights gathered through the interviews. Questionnaire data has been analysed using descriptive statistics and is reported elsewhere (Flintoff, 2008), however, due to space limitations, this paper draws on the interview data.

\section{Findings:}


One important point to make from the outset is that the research highlighted participants' differing experiences of PETE, and the significance of particular temporal moments (e.g. entering PETE for the first time) or spaces (e.g. between formal curriculum spaces and informal, social spaces, or between university and school placement settings). Students also attended five different universities, each of which will have different gender, 'raced' and classed 'regimes', reflecting their particular histories (see Flintoff, 1993a; b; Kirk, 1992). Not surprisingly, then, there is no common 'BME' experience of PETE, and we are very aware of the dangers of any generalisation ${ }^{6}$.

\section{PE - a young, male and White profession?}

In drawing on Anthias' organisational level of analysis, it is clear that PE (and PETE) is both gendered and racialised. As highlighted earlier, people from BME backgrounds are under-represented in the teaching profession as a whole, but specifically so within the subject area of PE. PE teaching is not just a career for the young and abled bodied, but is gendered, in both its practice, and leadership (Penney, 2002; Webb and Macdonald, 2007). It is also a White profession. In relation to leadership within PE, although similar numbers of men and women enter PETE, and go on to work as PE teachers in England, available figures suggest that young White men dominate leadership positions (Penney, et al, 2002). It is difficult to obtain specific information about BME PE teachers' career trajectories, or their position within the profession, because no overall data exist. However, research suggests that BME teachers in general, are less represented in senior leadership positions, and are more likely to teach in schools with multi- ethnic intakes, 
and with lower overall academic performance (Wilson, et al, 2006; Davidson, et al, 2006). We can infer from these patchy data that secondary PE teaching is a gendered and White institution, a position which has changed little over time.

Similarly, whilst data is scarce, some studies, supported by anecdotal evidence, suggest that those delivering PETE programmes are overwhelmingly White (Douglas and Halas, 2011). PETE cohorts are remarkably homogeneous, so new cohorts of teachers make little difference to changing the patterns described above. Most students are young, abled - bodied, successful sports performers, with conservative attitudes towards social justice issues (Brown and Rich, 2002; Dowling, 2011), and White, characteristics that have shifted little over time and are remarkable for their similarities across different (Western) countries (McCullick, et al, 2011). Set against this organisational picture, how then do BME students experience their PETE? The next section firstly explores some of the similarities between our participants and 'typical' PE students identified in previous studies, before moving onto their early experiences of being (and being made to feel) 'different' in PETE.

\section{Typical PE students?}

Our participants shared many of the characteristics and experiences of a 'typical' PE student. Experiencing success in school PE, and wanting to help other young people, are common reasons cited in the literature students choosing to enter PETE. Most of our participants had made an early decision to teach, having enjoyed successful and positive 
experiences of PE, and all but four were between 19-24 years of age, having moved into PETE through the 'traditional' route directly from school to higher education. In this sense, our participants are not dissimilar to their White counterparts described in other studies (e.g. Dowling, 2011; Armour and Jones, 1998), and they contrast with the demographics of BME students found in other studies of ethnicity and initial teacher education (ITE) (e.g. Carrington, et al, 2001), who tended to be older, and more often, career changers. These age differences may reflect the ongoing changing demographics of BME communities in the UK, but also common sense ideas that 'ability' in the teaching of PE centers on the ability to 'perform’ physical activities, - and as suggested above, positioning the profession as one more suited to the young.

As in other studies (e.g. McCullick, et al, 2011), an important motivator to enter PE for our participants was to improve young people’s experiences; however our research also showed that making a difference specifically for BME children was important too. Since racial harassment and bullying had been a part of at least some participants' own schooling, becoming a teacher was about being in a position to be able to challenge this with future generations. Nevertheless, many were wary of being positioned as 'professional ethnics’ (Blair and Maylor, 1993) - assumed to have specialised knowledge and expertise of minority ethnic cultures and customs - rather than teachers with a broad range of talents. Blair and Maylor highlight how such limiting stereotyping of Black teachers can lead to marginalisation and endanger their chances of success and promotion. Our data suggest that these kinds of fears by our participants were not unfounded. Stereotypical reactions by White peers, PETE educators and school teachers 
were common, particularly in the early experiences of entering PETE, as we explore below.

Entering the field

Being the only BME student on the initial visits to universities to be interviewed for a place, was an example of a moment when the Whiteness of PETE became glaringly apparent. For many of the Black and Asian students, realising that they may be the only BME student on the course came as a shock, raising doubts about whether or not they would fit in:

..the only other ethnic minority person on the interview was [name]...everyone else was of the White British majority. And I did have a conscious thought at the back of my mind 'Would I be the only Asian on the course?' ....the thought was there, and as the course went on it gradually faded away, it wasn't an issue for me towards the end. At the beginning it was, I felt scared, and I thought I might be left out on certain occasions. They might not talk to me. But it was okay as the course went on [Student 18].

A Muslim, mixed 'race' woman recounted how, in the first moments of entering one university, she was assumed to be there for a dance, rather than for a PE, teacher education interview: 
....when I went to [another] university and I sat there with the other applicants, and I was there in my headscarf, and the receptionist thought I was there for a dance or a drama interview, as opposed to the PE because I didn't look right... And it put me off, whereas when I came here, you know, straightaway it was not a problem; it was just, you're just another applicant, which is what I've always just tried to be [Student 15].

The assumptions and stereotypes about this student's religious, ethnic and gendered identity resulted in her being positioned as 'out of place' in her very first moments of trying to enter PETE, an experience that was significant enough for her to withdraw from this particular university course. Other mixed race students, without the visible markings of religious dress, reported a less problematic transition into PETE. They had experienced being part of overwhelmingly White cohorts before, on their undergraduate programmes, and often in their schooling, so had come to expect little else on their teacher education course. However, some reported being 'read' by their peers as White, a source of frustration - although they also admitted that this may have contributed to their experiences of racism being low. Such data point to the need to for an intersectional approach to analysis that recognises diversity within and across groups such as 'Asian', or 'Muslim', and one that moves beyond simple black/white boundaries, to include acknowledgement of 'new ethnicities and racisms, including 'non-colour' coded forms such as Islamophobia’ (Cole, 2009). 
Being 'read' as White was not possible for the Black or Asian students, where skin colour marked them out as different to the majority of their peers. Indeed, entry in PETE had resulted in some developing a heightening sense of their own ethnicity:

It is only when I have come to uni [university] that I have actually realized more so that I am an ethnic minority because where I come from, I am not an ethnic minority [Student 24].

Other research has reported on the challenges of negotiating a place within universities for students positioned as 'different' because of their social class, ethnicity and/or religion (e.g. Bagguley and Hussain, 2007; Reay, et al, 2001). In relation to PETE, Fitzpatrick’s (2011) research explores the ambiguities and tensions felt by a working class, Maori teacher education student, Renee, as she negotiates a position for herself within and across the social 'fields' of PETE and her home life. PETE programmes are not only a space where physical capital is valued, but it is also one of intellectual engagement. In relation to both of these aspects, Renee's experiences her Maori background in contradictory ways - stereotypes of the 'brown"7 body assume 'natural' physical capital, but a concomitant lacking in intellectual worth.

Some of our participants experienced similar stereotyping. Despite their high levels of school achievement, six students recounted incidences, early in their transition onto the course, where their academic credentials were questioned, and where their place on the 
course had been attributed to the institution's attempts at meeting their so-called 'race' targets $^{8}$, rather than their individual abilities;

I know it was really hard to get on the PGCE and I know there were 2,000 applicants, that is what I was told. But I think if you work really hard, you get chosen don't you? I remember some people on the PGCE and I just ignored it but they said to me you only got on the course because you are Asian and they had to put you down, tick that box. [Student 9].

This Black student had similar experiences:

Well, I remember in the first year...we were just talking about what grades we had to get on with the course, then I just said, oh, well, I did a BTEC National Diploma $^{9}$, and someone said, but they don't count, they're low, you're getting in on the 'race' card! I was thinking, hey? [Student 5].

These comments show how the TDA's policy of target setting, designed to support institutions in their efforts to address the ethnic imbalance of their PETE cohorts, is misappropriated and reproduced instead as a 'lowering of standards' discourse, a form of 'everyday racism' (Essed, 2001), that works to inferiorise their BME peers. Whilst our participants were more likely to dismiss these experiences as 'only jokes', or as nativity or unwitting prejudice on the part of White students rather than 'deliberate' racism, nevertheless, like Wilkins and Lall, 2011), we suggest these are significant interactions 
that, in a racialised society, demonstrate how much of such 'everyday' racism goes unnoticed and un-remarked, because it is so 'normalised'.

Our data provide insights into how gender and race are produced through the distribution of power within the organisational structures of PETE, a space controlled by White lecturers, and occupied by White students. BME students' early experiences of PETE reflect these organisational characteristics and policies, producing particular social relations of power.

\section{Different bodies, different capital}

Practical PE sessions are an important space within PETE valued by students ahead of theory as the 'most useful' knowledge in their quest to become teachers (Dowling, 2011). Our study showed that these were key contexts in which processes of differentiation via stereotyping of BME students were evident. PE practical sessions are environments where students' and teachers' bodies (and therefore their 'capabilities') are very much on show, and are appraised and assessed (Webb and Quennerstedt, 2010). All three of our Black male students had been on the receiving end of stereotypical comments or assumptions about their physical abilities:

Obviously you just get normal things that happen in everyday life, but nothing... Well, if we're playing, in our practical activities, like before anyone's seen me play, I'm getting picked first, so like......When we was doing athletics. No one had 
ever seen me run at this ..uni [university] because I did boxing and you don't see anyone running and no one off my class even went to boxing. But we were doing athletics and I was just assumed to be the fastest for 100, so I had to get videoed [Student 5].

Later in the interview, this student told us that when he had been completing his Criminal Records Bureau (CBR) documentation ${ }^{10}$ someone had joked about his supposed 'criminal offences':

what have you put [student's name]?!! Just said as a joke, in passing. And it doesn't bother me a lot. Maybe that's because I'm Black or maybe it's because I'm from the area that I live near, maybe it's both. It probably is both. You're just bear it, it's just there [Student 5].

This student's comments illustrates the pervasiveness of racialised discourses and their impact on his life...for him, they're 'normal', 'happen in everyday life' and things 'to bear', and to be expected.

Two other Black students experienced swimming as a particularly uncomfortable environment, admitting to struggling against the impact of everyday stereotypes 'that black people can't swim': 
... yeah I felt kind of funny doing the swimming module just because like you know there's a stereotype of black people who can't really swim and I was a terrible swimmer you know, I was perpetuating that stereotype, it was quite funny in a way. I was trying my best to swim but actually I can't swim that well .... What can I do? [Student 4].

Something like swimming I've kind of struggled a bit on and that's just purely because people have got this assumption that because you're black you can't swim or don't know how to swim. It's not necessarily the case, because I've passed the first two years of swimming without a problem but that's just sort of one area that you sort of walk into and people are like..... you sort of feel as though everybody is looking at you.. [Student 23].

Swimming was also the practical activity that caused the most difficulty for two of the Muslim women students. Whilst many young women feel ill-at-ease in mixed swimming sessions (see Flintoff and Scraton, 2001), the religious requirement to ensure modesty in mixed settings poses particular issues for Muslim women. Indeed, Benn and Dagkas (2006) have argued that the practice of mixed sex PETE in England is incompatible with the needs of Islamic students. For our Muslim women, the religious requirement to cover their bodies in mixed settings was accommodated in different ways by different students across the institutions. For example, one student was too nervous to explain why she was unable to join in the mixed swimming class, and it was only when her tutor insisted that the practical involvement was compulsory, did she revealed her reluctance was for 
religious adherence reasons. The 'solution' here was for the student to attend the sessions, but work from the poolside. In contrast, another student opted to join in practical swimming lessons, but recounted the extra stress placed upon her by having to swim with several layers of clothing covering her body. A third student, describing herself as 'very Westernised', wore a swimsuit like the White students, but still admitted to feeling somewhat uneasy about how others might judge her, particularly male students, in choosing to teach swimming in shorts and a tee-shirt whilst on school placement.

These examples illustrate the importance of detailed analysis at the experiential and inter subjective levels, to show how racialised and gendered processes operate in specific ways across different spaces for different students. Practical PE lectures were contexts where ethnic and religious difference was specifically highlighted, serving to normalise 'racialised notions of Whiteness $=$ normal; Blackness $=$ Otherness' (Wilkins and Lall, 2011, p. 374). However, they also point to the particular nature of racialised discourses of embodiment that operate to position men and women students differently, and how these are negotiated by individual students in different ways. Skin colour, and visible signs of religious identity were significant to Black and Muslim students being defined as different; Whiteness on the other hand went unmarked. Our interviews with mixed race students who were able to 'pass' as White did not report any such experiences. It seems that stereotyping based on the 'natural' physical capabilities of Black athletes, identified in earlier research (e.g. Hayes and Sugden, 1999; Long, et al, 1997) or assumptions about the impact of negative impact of ‘cultural background' on Asian women's participation in sport (e.g. Benn, et al, 2011) have not been dispelled, and as we discuss below, are 
largely going unchallenged within contemporary PETE practice. Our research showed that BME students negotiated a position for themselves in this 'colour blind' PETE (Burden, et al, 2004), largely through compromise and adjustment, and often through a down-playing of their ethnic or religious identities.

\section{'Race', ethnicity and racism as professional knowledge}

In this section, the nature of discourses around 'race' and ethnicity within the PETE programmes are considered. In relation to Anthias' fourth level of analysis, what kinds of representations of BME pupils are made available within PETE, and how do students position themselves, and are positioned, in relation to these? All students have to demonstrate that they can work effectively with BME pupils, and those with English as an Additional Language (EAL) as part of meeting the TDA's (2007) Professional Standards for Teaching. In this sense, an awareness of the impact of 'race' and ethnicity on pupils' education is part of the official discourse of teacher education. However, as Lander (2011) notes, it is one thing to have a formal written requirement as part of the TDA's professional standards, it is another how this is enacted within teacher education programmes. Recent research suggests that less than half of new entrants to the teaching profession rate this aspect of their course as good or very good (TDA, 2011). The shift in teacher education towards practical based competencies and skills and away from reflection and theoretical concerns evidence in the 1980a and 1990s (Mahony and Hexall, 1997) has left very little space for equity issues to be addressed. Attempts to engage White student teachers in 'race' as a professional issue are challenging for teacher 
educators; research has characterised student responses as resistance, confusion or naivety (e.g. Lander, 2011; Gaine, 2001). Little is known, however, about BME students' views of 'race' and racism as professional issues for teachers.

In reflecting on how well they felt their course had prepared them to teach in a multicultural society, we were not surprised to learn of a mixed picture in terms of how and where such issues were addressed. Whilst all students remembered sessions where 'race' and ethnicity were addressed (with more emphasis evident in the longer undergraduate programmes, than within the one year PGCE course) these were described more often as having been 'touched upon', or the focus of 'one lecture'. In contrast, many more remembered useful sessions which were 'practically focused' on helping students with EAL, for example, or on how to modify physical activities to include children with disabilities. None of the participants had been engaged in discussing issues of 'race' or racism in their school placements, a significant finding, given that this is the aspect of training that students value the most.

Participants' evaluations of these sessions differed significantly, with almost half tending to view the sessions on 'race' and ethnicity as somewhat unnecessary to their professional development, arguing that good teaching was good teaching, regardless of pupils' ethnicity, and in times when, to quote one student, 'no one is really racist'. 
I don't know, I think people seem pretty clued up, whether that is part of the interview process, picking the right people to do the course. I don't think so, I don't think there are any issues ethnically [Student 20].

Only a small number of students argued strongly for the importance of these sessions and had been positively engaged in developing their own understanding and knowledge to take forward into their work as teachers. Some students reported being used as a 'resource' in discussions to give their perspectives on issues of 'race', ethnicity and religion; however only one Muslim woman seemed to relish this challenge, drawing on her own religious identity to present a seminar on Islam and PE. Others felt uncomfortable with the assumption that they would be the 'experts', and be able to speak on behalf of a particular group, yet admitted to being 'frustrated and angry' at having to listen to uninformed White students' views of BME pupils. The dominant representation of BME pupils was one of deficit, of lacking in relation to a White 'norm'. Only one student talked about a session that had switched the focus from such a 'deficit approach' towards BME pupils and their education (Mirza, 2009) to a focus on Whiteness and privilege, describing the difficulty of his White peers in reflecting upon their own ethnicity.

Being from a BME background, however, was not in itself a guarantee of a politicized understanding of racial or other forms of inequalities. As we discuss elsewhere (Flintoff and Webb, 2012), some students, mostly men, talked stereotypically about pupils from different ethnic or gender groups, using words such as ‘ethnics' or more usually ‘them' to 
describe BME pupils, and stereotyping, for example, Asian girls as disinterested, or not able to participate in PE because of their cultural background. There was no clear pattern as to which students appeared more politicised. Gaine (2001) has suggested individual biographies may be important to how receptive individual students are to acknowledging racism as part of their professional responsibilities. We can only speculate on the extent to which this might be true with our participants. Our data does suggest that, for at least some of our participants, their teacher education have been unsuccessful in helping them see the links between the personal and professional in relation to 'race' and ethnicity. It also supports previous research (e.g. Lander, 2011) that shows that 'race' and ethnicity represent, at best, a marginalised discourse within teacher education, and at worse, one that reproduces a simplistic, deficit perspective on BME pupils' schooling and PE.

\section{Ethnic and religion difference as a pedagogical resource?}

Whilst teaching practice is often viewed by students as the most important element of their course, it is also a context in which relationships are inevitably unbalanced in relation to power, with school tutors having considerable influence over whether or not a student is deemed suitable to successfully complete their course. Many students adopt copying strategies designed to simply 'get them through' the placement (e.g. Sirna, et al, 2008); for BME students, some research suggests that racism can play a part, although students are, understandably, reluctant to complain (Basit et al 2005). 
Our participants admitted that part of their nervousness had been concerns over the reception they would receive if placed in predominantly White schools. Memories of what one called 'low level' racism in their own schooling - verbal, and occasionally physical, abuse - were at the back of some students' minds as they prepared to go back into schools as student teachers. Few had had any say in where they were placed for their school practice, resulting in quite distressing experiences for a minority. For example, one student had been initially placed in a school in an area known for National Front ${ }^{11}$ activism. Whilst our students agreed the importance of all teacher candidates having experience of multi-ethnic school placements, our questionnaire data revealed that almost half (twelve students) had only experienced teaching in mainly White schools Institutions’ arrangements for teaching placements are a crucial aspect of their teacher preparation courses, and we suggest that this data alone represents one of the processes that contribute to the continuing Whiteness of PETE. Students' experiences of teaching practice suggest that issues of 'race' and ethnicity were not part of the institutions' practice of allocating 'appropriate' school placements: One student described his dismay when he found out that his first school placement was at a predominantly White, private boys' school:

I described it as Harry Potter, the school was like Harry Potter to me; it was out of my world! It was nothing like what I was used to at all....It was ethnically wrong to put somebody coming from [large metropolitan area] into a school [like that], and they know where I have come from, they know the kind of background that I have and to put me in a school like that! [Student 24]. 
Without the strong support of his university mentor, this student admitted he would have withdrawn from his course.

Overall, our data suggested that students experienced relationships with pupils as easier than with (at least some of) teachers. Only one out of twenty five interviewees reported experiencing a racist incident (a racist comment) from a pupil in school serious enough to report it, which had been dealt with promptly and efficiently. However, as noted earlier, we suggest that there may have been an under-reporting of difficult issues with pupils on teaching practice for fear of being seen as not being able to cope. Young pupils' first reactions to their student teachers' ethnic difference were most often ones of curiosity, asking questions about where they were from, how to pronounce their name, or for the Muslim students, about their religion.

In contrast, some of the more difficult experiences reported by our students involved their relationships with staff or other students. One or two told us they had sensed tutors' 'surprise' when meeting them for the first time and realising they were from a BME background; others talked about decidedly 'chilly' atmospheres with some tutors, or inappropriate comments being made about their dress. One Black student recounted feeling that he had had less support from his mentor in preparing GCSE classes compared to his two White counterparts; a mature Muslim woman had to be moved schools when relationships with her younger, White mentor had become so strained, and another Black student had decided to take a year out to reconsider whether he wanted to teach, given the 
'difficult time' he had had on his course. This data illustrate something of the complexity of understanding students' experiences of PETE. All students experience the challenges of relating to different pupils and teachers as part of their training, and in this sense, BME students are no different to White students; however our data provides us with some evidence of 'race' and gender relations impacting on these, albeit in complex and dynamic ways. Our overall sense was just as 'race' and ethnicity were marginalised as professional issues in the university-based aspects of PETE, they were equally invisible as acknowledged aspects of students' teaching placement.

However, interview data can provide only a limited insight into how the organisational 'regimes' of schools and universities construct gender, 'race' and class and their impact on students' experiences, suggesting the need for further research (e.g. building on Sirna, et al, 2008; 2010; Laker, 2003), and drawing on different methodologies to better understand these dynamic and complex processes. One of the key reasons we included an anonymous questionnaire as part of the methodology was to allow students the space to tell us, anonymously, about any experiences too difficult to recount in person. Few students suggested that they had been on the receiving end of racist harassment during their training, either in the questionnaire or in the interviews. However, we are very aware of the ways in which 'racism' may be a silenced discourse in interactions between BME participants and White researchers (see Archer, 2002). Two Asian women students did tell us about incidents of abuse that happened outside of the university context - one student suffered a fractured eye socket as a result of a physical attack and the other, verbal abuse from young men at the bar where she was socialising with friends. One was 
quite philosophical about her physical attack, suggesting that she knew that in choosing to study PE as a Muslim woman, she was challenging the 'norms of that environment'. Whilst training within the context of 9/11 terrorist attacks had been difficult, she suggested that this had made her even more determined to challenge Islamophobia and succeed as being 'different' within PE. Our data can only provide glimpses of the difficult circumstances faced by some of our BME students. These show how racialised discourse work to position students in different ways, depending on their individual identities, and how these 'rub up’ against particular institutional contexts of universities and schools. In adopting a 'colour blind' approach to 'race', through ignoring ethnic difference, and not ensuring that 'race' and ethnicity are professional issues explicitly addressed in university, and in school placement, our data illustrates how PETE reproduces its taken-for-granted Whiteness.

\section{Concluding remarks}

Whilst our study cannot be taken to be representative, it nevertheless contributes to our understandings of the different ways in which BME students experience 'race', ethnicity and gender within PETE in England. The research has shown much commonality between our participants and those of White students reported in other studies, but also how racialised power relations construct them as different, albeit in complex and dynamic ways. Most of our participants were young, with positive sport experiences and a conviction that they will be able to provide an improved PE experience for youngsters. But the data also shows how they share similar experiences of racism with other BME 
students and teachers. The interview data shows the importance of acknowledging the intersections of gender, religious and class with ethnicity; these are interwoven in participants' experiences in complex and nuanced ways, across different moments and spaces within PETE. Skin colour and religious dress were central to the racial stereotyping experienced by some of our participants. The embodied nature of PE provides a unique context for educators to challenge racial, ethnic and religious stereotyping and discrimination, but our data suggests the opposite may well be the case, that stereotyping around embodied difference is an everyday occurrence within PETE. Our study shows the colour blind nature of PETE and the 'weighty silence' (Douglas and Halas, 2011) around ethnic difference and racism that is perpetuated by its practices, including in its professional discourse.

In adopting a middle ground, intersectional approach, and centralising 'race' and ethnicity, the research has sought to build on our existing knowledge and understandings of students' experiences of PETE. Although conducted in English university settings, we suggest that our findings have wider significance for programmes in other countries, not withstanding their important differences in 'race' relations and university/PETE cultures. The implications are far reaching, and entail, not least, working towards a much higher visibility of equity issues in general, and of 'race' and racism in particular, as central to PETE's professional knowledge and pedagogy. However, we do not underestimate the scale of this challenge and what it might mean in practice. ${ }^{12}$. Whilst as a profession, we have not been afraid to explore the challenges of promoting critical reflection with our 
students, arguably we have been less willing to do so in relation to ourselves as teacher educators. As Lander (2011, p. 362) stresses,

It is not until we begin to question the neutral White position promoted by ITE policy and practice that we will begin to make a real difference to how student teachers perceive themselves in relation to their BME pupils and their position as educators in a multiracial society.

We hope that this study contributes in a small way to beginning this task.

\section{Acknowledgements}

Thanks are due to the students that gave up their time to take part in the research and shared their experiences so willingly with us, and also to the full research team - without their help, the project could not have been completed. They are: Anne Chappell, Cathy Gower, Saul Keyworth, Julia Lawrence, Julie Money, Sarah Squires and Louisa Webb. This article is dedicated to Louisa Webb who lost her life to cancer in January 2012.

\section{References}

Anthias, F. (1998) Rethinking social divisions: some notes towards a theoretical framework, The Sociological Review, 46, 506-535. — (2001) The Concept of 'Social Division' and Theorising Social Stratification: Looking at Ethnicity and Class, Sociology, 35, 835-854. 
— (2008) Thinking through the lens of translocational positionality: an intersectional frame for understanding identity and belonging, Translocations: Migration and Social Change An Inter-Disciplinary Open Access E-Journal, 4, 5-20.

Archer, L. (2002) 'It's easier that you're a girl and that you're Asian: interactions of 'race' and gender between researchers and participants, Feminist Review, 72, 108-132.

Archer, L., Hutchings, M., \& Leathwood, C. (2001) Engaging in Commonality and Difference: theoretical tensions in the analysis of working class women's educational discourses, International Journal of Sociology of Education, 11, 4162.

Armour, K. M., \& Jones, R. L. (1998) Physical Education: Teachers' Lives and Careers (London, Falmer).

Bagguley, P., \& Hussain, Y. (2007) The Role of Higher Education in Providing Opportunities for South Asian Women (Bristol, Polity Press).

Basit, T., Kenward, J., \& Roberts, L. (2005). Tackling racism on school placements [Internet]: Multiverse. Available from www:Multiverse.org.uk [accessed 4th January 2008].

Basit, T., Roberts, L., Mcnamara, O., Carrington, B., Maguire, M., \& Woodrow D (2006) Did they jump or were they pushed? Reasons why minority ethnic trainees withdraw from initial teacher training courses, British Educational Research Journal, 32, 387-410.

Benn, T. (1996) Muslim women and physical education in initial teacher training, Sport, Education and Society, 1, 5-21. 
— (2002) Muslim women in teacher training: issues of gender, 'race' and religion, in: D. Penney (Ed) Gender and Physical Education: contemporary issues and future directions (London, Routledge), 57-79.

Benn, T., \& Dagkas, S. (2006) Incompatible? Compulsory mixed-sex Physical Education Initial Teacher Training and the inclusion of Muslim women: a case study on seeking solutions, European Physical Education Review, 12, 181-200.

Benn, T., Dagkas, S., \& Jawad, H. (2011a) Embodied faith: Islam, religious freedom and educational practices in education, Sport, Education and Society, 16, 17-34.

Benn, T., Pfister, G., \& Jawad, H. (2011b). Muslim Women in Sport. London: Routledge. Blair, M., \& Maylor, U. (1993) Issues and Concerns for Black Women Teachers in Training, in: I. Siraj-Blatchford (Ed) 'Race', Gender and the Education of Teachers (Buckingham, Open University Press), 54-73.

Bonnett, A., \& Carrington, B. (2000) Fitting into Categories or Falling Between Them? Rethinking ethnic classification?, British Journal of Sociology of Education, 21, 487-500.

Brah, A. (1996) Cartographies of Diaspora: Contesting Identities (London, Routledge).

Brown, D., \& Rich, E. (2002) Gender positioning as pedagogical practice in physical education, in: D. Penney (Ed) Gender and Physical Education: contemporary issues and future directions (London, Falmer), 80-100.

Burden, J., Jr,, Hodge, S., O'bryant, C. P., \& Harrison, L., Jr (2004) From Colourblindness to Intercultural Sensitivity: Infusing Diversity Training in PETE programmes, Quest, 56. 
Carrington, B., Bonnett, A., Demaine J, Hall I, Anoop N, Short G, Skelton C, Smith F, \& Tomlin, R. (2001) Ethnicity and the Professional Socialisation of Teachers [Internet] (London, Teacher Development Agency, Available from http://www.tda.gov.uk/partners/recruiting/consultationdata.aspx [accessed 28th Feb 2008]).

Cole, M. (2009) A plethora of 'suitable enemies': British racism at the dawn of the twenty-first century, Ethnic and Racial Studies, 32, 1671-1685.

Commission for Racial Equality (2002) The duty to promote race equality; a guide for further and higher education [Internet] (London, Commission for Racial Equity. Available from: www.cehr.gov.uk, [Accessed 2nd Feb 2008]).

— (2008) Ethnic Monitoring: A Guide for Public Authorities [Internet] (London, Commision for Racial Equality. Available from www.cehr.gov.uk [Accessed 1st Feb, 2008]).

Davidson, J., Powney, J., Wilson, V., Hall, S., \& Mirza, H. S. (2005) Race and sex: teachers' views on who gets ahead in schools?, European Journal of Teacher Education, 28, 311-326.

Davies, K. (2009) Intersectionality as buzzword. A sociology of science perspective on what makes a feminist theory successful, Feminist Theory, 9, 67-85.

Douglas, D., \& Halas, J. (2011 (iFirst article)) The wages of whiteness: confronting the nature of the ivory tower racism and the implications for physical education, Sport Education and Society DOI: 10.1080/13573322.2011.602395, 1-22.

Dowling, F. (2008) Getting in touch with our feelings: the emotional geographies of gender relations in PETE, Sport, Education and Society, 13, 247-266. 
— (2011) 'Are PE teacher identities fit for postmodern schools or are they clinging to modernist notions of professionalism?' A case study of Norwegian PE teacher students' emerging professional identities, Sport Education and Society, 16, 201222.

Dowling, F., Fitzgerald, H., \& Flintoff, A. (eds) (2012) Equity and difference in physical education, youth sport and health: A narrative approach (London: Routledge).

Evans, J., \& Williams, T. (1989) Moving up and getting out: the classed and gendered career opportunities of physical education teachers, in: T. Templin \& P. Schempp (Eds) Socialisation in PE: Learning to teach (Indianapolis, Benchmark Press), 235-249.

Fitzpatrick, K. (2011 (iFirst)) Brown bodies, racialisation and physical education, Sport, Education and Society DOI:10.1080/13573322.2011.559221, 1-19.

Flintoff, A. (1993a) Gender, Physical Education and Teacher Education, in: J. Evans (Ed) Equality, Education and Physical Education (London, Falmer), 184-204.

— (1993b) One of the boys? Gender identities in Physical Education initial teacher education, in: I. Siraj-Blatchford (Ed) 'Race', Gender and the education of teachers. (Buckingham, Open University Press), 74-93.

Flintoff, A., Fitzgerald, H., \& Scraton, S. (2008) The Challenges of Intersectionality: Researching difference in Physical Education, International Studies in Sociology of Education, 18, 73-85.

Flintoff, A., \& Scraton, S. (2001) Stepping into Active Leisure? Young Women's Perceptions of Active Lifestyles and their Experiences of School Physical Education, Sport Education and Society, 6, 5-22. 
Flintoff, A., \& Webb, L. (2012) 'Just open your eyes a bit more': researching black and minority ethnic trainees' experiences of physical education teacher education, Sport, Education and Society, 17, 571-589.

Gaine, C. (2001) If it's not hurting it's not working: teaching teachers about 'race', Research Papers in Education, 16, 93-113.

Guba, E. G., \& Lincoln, Y., S. (2005) Paradigmatic Controversies: Contradictions and Emerging Confluences, in: N. Denzin \& Y. Lincoln, S. (Eds) The Sage Handbook of Qualitative Research (3rd Edit) (London, Sage), 191-215.

Gunaratnam, Y. (2003) Researching 'Race' and Ethnicity: Methods, Knowledge and Power (London, Sage).

Hayes, S., \& Sugden, J. (1999) Winning through 'Naturally' Still? An Analysis of the Perceptions Held by Physical Education Teachers towards the Performance of Black Pupils in School Sport and in the Classroom, Race Ethnicity and Education, 2, 93-108.

Kirk, D. (1992) Defining Physical Education: The Social Construction of a Subject in Postwar Britain (Basingstoke, Falmer Press).

Lander, V. (2011) Race, culture and all that: an exploration of the perspectives of White secondary student teachers about race equality issues in their initial teacher education, Race, Ethnicity and Education, 14, 351-364.

Lander, V. (2012) Transforming racist behaviour: a small scale study of racist incidents in higher education, paper presented at the, British Educational Research Association Annual Conference. Manchester. 
Long, J., Carrington, B., \& Spracklen, K. (1997) 'Asians Cannot Wear Turbans in the Scrum': Explanations of racist discourse within professional rugby league, Leisure Studies, 16, 249-259.

Long, J., Hylton, K., Sparklen, K., Ratna, A., \& Bailey, S. (2009). Systematic Review of Literature on Black and Minority Ethnic Communities in sport and physical recreation. Leeds: Carnegie Research Institute, Leeds Metropolitan University, for The UK Sports Councils and Sporting Equals.

Mahony, P., \& Hexhall, I. (1997) Sounds of silence: The social justice agenda of the teacher training agency, International Studies in Sociology of Education, 7, 137156.

Maynard, M. (2002) Studying age, 'race' and gender: translating a research proposal into a project, International Journal of Social Research Methodology, 5, 31-40.

McCullick, B., Lux K, M., Belcher, D., \& Davies, N. (2011 iFirst) A portrait of the PETE major - re-touched for the early twenty first century, Physical Education and Sport Pedagogy, http://dx.doi.org/10.1080/1748989.2011.565472, 1-7.

Mirza, H. S. (2009) Race, Gender and Educational Desire: Why Black Women Succeed and Fail (London, Routledge).

Nelson, A. (2011 iFirst) 'You don't have to be black skinned to be black': Indigenous young people's practices, Sport Education and Society, DOI: 10.1080/13573322.2011.559221.

Penney, D. (2002) (ed) Gender and physical education: contemporary issues and future directions'. London: Routledge. 
Penney, D., Houlihan, B., \& Eley, D. (2002) Report of the first National Survey of Sports Colleges (Loughborough, Institute of Youth Sport, Loughborough University).

Reay, D., Davies, J., David, M., \& Ball, S. J. (2001) Choices of Degree or Degrees of Choice? Class, 'Race' and the Higher Education Choice Process, Sociology, 35, 855-874.

Scraton, S., Caudwell, J., \& Holland, S. (2005) Bend it like Patel: Centering 'Race', Ethnicity and Gender in Feminist analysis of women's football in England, International Review for the Sociology of Sport, 40, 71-88.

Sirna, K., Tinning, R., \& Rossi, T. (2008) The social tasks of learning to become a physical education teacher: considering the HPE subject department as a community of practice, Sport, Education and Society, 13, 285-300.

Teacher Development Agency (2008) Statistics provided on request by personal communication, February 2008.

Training and Development Agency (2007). Professional Standards for Teachers in England: Qualified Teacher Status. London, Training and Development Agency.

— (2011). Results of the newly qualified teacher survey 2011 [Internet]: Training and Development Agency. Available from: www.tda.gov.uk [Accessed 15th March 2012].

Turner, D. (2007) Ethnic Diversity in Physical Education Teaching, Physical Education Matters, 2, 14-16.

Valentine, G. (2007) Theorizing and researching Intersectionality: A challenge for feminist geography, The Professional Geographer, 59, 10-21. 
Webb, L., \& Quennerstedt, M. (2010) Risky Bodies: health surveillance and teachers' embodiment of health, International Journal of Qualitative Studies in Education, 23, 385-802.

Webb, L. A., \& Macdonald, D. (2007) Dualing with gender: Teachers' work, careers and leadership in physical education, Gender and Education, 19, 491-512.

Wilkins, C., \& Lall, R. (2011) 'You've got to be tough and I'm trying': Black and minority ethnic student teachers' experiences of initial teacher education, Race, Ethnicity \& Education, 14, 365-386.

Wilson, V., Powney, J., Hall, S., \& Davidson, J. (2006) Who gets ahead?: The effect of age, disability, ethnicity and gender on teachers' careers and implications for school leaders, Educational Management Administration \& Leadership, 34, 239255.

\footnotetext{
Endnotes

${ }^{1}$ A limitation of this research is its lack of analysis of social class and sexuality. We suggest this has less to do with the classed and (hetero)sexualized nature of PETE, and more a reflection of the practical challenges of doing intersectional research (see Maynard, 2002).

${ }^{2}$ Macdonald and Kirk’s (1999) small scale, exploratory study explored the relationships between Christian PETE students' religious identities and their pedagogies in health and PE, and suggested their Christian 'self' seemed constant across different contexts of their lives. The differences in how Muslim students manage the private/public manifestations of their faith may be explained by the rise of Islamophobia, and the racialisation of Islam (see Benn, et al, 2011).

${ }^{3}$ Term used in Canada to denote 'persons other than Aboriginal peoples, who are non-Causasian in race or non-white in colour' (Douglas and Halas, 2011, p.20).
} 
${ }^{4}$ The funding limited the research to five institutions; each was located in areas with significant BME populations.

${ }^{5}$ Lecturers involved in the PETE programmes from each institution were involved in recruiting participants, conducting interviews, and the initial analysis of data. The full research team is acknowledged at the end of the paper.

${ }^{6}$ Other methodologies, such as ethnography, would offer different insights into students' experiences. Also our research could not tell us much about the different courses, or institutional contexts - avenues for future research.

${ }^{7}$ A term young Maori people used to refer to themselves.

${ }^{8}$ One of the TDA's strategies for promoting ethnic diversity in teacher education is to allocate 'targets' for institutions to try to achieve, although their effectiveness is questioned (Callender, 2007).

${ }^{9}$ BTEC are vocational qualifications, offered as an alternative to the more traditional, so-called 'academic' Advanced level General Certificate of Educations commonly accepted as entry requirements for PETE in England.

${ }^{10}$ All students have to gain a Criminal Records Bureau certificate confirming that they are safe to work with young people or vulnerable adults, before starting their teaching placements.

${ }^{11}$ A British far right, racial nationalist, whites-only political party

${ }^{12}$ See Dowling, Fitzgerald and Flintoff (2012) for how narrative could be used in educating about equity and diversity. 